ISSN 1392-3196 / e-ISSN 2335-8947

Zemdirbyste-Agriculture, vol. 100, No. 3 (2013), p. 277-282

DOI 10.13080/z-a.2013.100.035

\title{
Impact of the short-term mild and severe ozone treatments on the potato spindle tuber viroid-infected tomato (Lycopersicon esculentum Mill.)
}

\author{
Asta ABRAITIENE' ${ }^{1}$, Raselè GIRGŽDIENE் $\dot{1}^{1,2}$ \\ ${ }^{1}$ Institute of Biotechnology, Vilnius University \\ V. A. Graičiūno 8, Vilnius, Lithuania \\ E-mail: asta.abraitiene@bti.vu.lt \\ ${ }^{2}$ Institute of Physics, Center for Physical Sciences and Technology \\ Savanorių 231, Vilnius, Lithuania \\ E-mail: raseleg@ktl.mii.lt
}

\begin{abstract}
This study was the first attempt to find out if the phenotypic plant response to the short-term ozone exposure might be altered by the presence of systemic viroid infection in plants. Model pathosystem used in these experiments was formed from the tomato (Lycopersicon esculentum Mill.) cv. 'Micro-Tom' and potato spindle tuber viroid. Viroid-infected plants were exposed to chronic, acute and extreme ozone treatments in order to find out if the elevated concentration of ozone could have any significant impact on the pathogenicity and spread of sub-viral pathogen. The results revealed that phenotypic alterations caused by the presence of viroid infection in plants were highly dependent on the dose of ozone received by plants. Only slight yellowing of the plant top leaves was detected in plants exposed to $80 \mathrm{ppb}$ of ozone for 8 hours. No significant differences between viroid-inoculated and uninoculated plants were observed in the phenotypic appearance as well as in plant growth after application of this treatment suggesting that naturally occurring single short-term peaks of elevated ozone concentration could have no significant impact on viroid and host interaction. There were no significant differences observed in the degree of visible ozone injury between viroid-inoculated and uninoculated plants just after the short-term acute $(400 \mathrm{ppb} \times$ $6 \mathrm{~h})$ and extreme $(300 \mathrm{ppb} \times 13 \mathrm{~h})$ ozone treatments were applied. However, in the end of the growth period clearly expressed differences in plant growth, degree of defoliation and the regeneration capacity were revealed between viroid-inoculated and uninoculated plants submitted to these treatments, indicating that pathogenicity of potato spindle tuber viroid could be altered by the exposure of inoculated plants to the severe ozone stress.
\end{abstract}

Key words: pathogenicity, potato spindle tuber viroid, short-term ozone treatment.

\section{Introduction}

It has been well documented that high concentration of tropospheric ozone is harmful to plants (Morgan et al., 2003; Hayes et al., 2007; Booker et al., 2009). It affects many aspects of plant life including plant disease development and co-evolutionary relationships between plant and pathogens. Many studies have been done to reveal the impact of ozone on bacterial and fungal diseases. However, much less information about ozone effect on viral diseases is available (Sandermann, 1996; Krupa et al., 2001).

Controversial information about the effect of elevated ozone concentration on virus-caused plant diseases was obtained from the experimental studies. It has been reported that enhanced resistance to ozone injury is induced by bean common mosaic virus (Davis, Smith, 1974), tobacco mosaic virus (Brennan, Leone, 1969; Ormrod, Kemp, 1979), tobacco ring spot virus (Vargo et al., 1978). On the contrary, elevated ozone concentration completely eliminated the effect of barley yellow dwarf virus on biomass reduction in wild oat (Pollina et al., 2008). According to Reinert and Gooding (1978), ozone reduced the suppression of tobacco etch virus on leaf and stem dry weight. In some studies growth has been significantly reduced in plants exposed to ozone after certain virus incubation period (Reinert, Gooding, 1978; Ormrod, Kemp, 1979). No significant virus and ozone interaction was found for plants inoculated with peanut stunt virus (Heagle et al., 1992) and tobacco streak virus (Reinert, Gooding, 1978). The major reason why such variable results were obtained could be a high number of factors having an impact on the final effect. The variation in ozone-caused injury degree was found to be influenced by growth conditions, virus species, and plant cultivar or even clone, ozone treatment conditions and virus incubation period.

More recent studies have shown many similarities between the plant responses to ozone and pathogens. Oxidative stress induced cell death pattern 
in plants resembling the resistance $(R)$ gene-mediated host defence response caused by pathogens (Rao, Davis, 2001; Overmyer et al., 2005). Advances in microarray technologies revealed statistically significant changes in a high number of genes that altered transcriptional activity as a result of treatment with elevated ozone concentration of virus-infected plants (Bilgin et al., 2008). Such evidence suggests high importance of ozone, plant and virus interaction on the spread and development of viral disease under the pressure of atmospheric pollution.

Viroids are the smallest causative agents inducing virus like disease symptoms in plants. They are classified into two Pospiviroidae and Avsunviroidae families of subviral particles that are formed of small single-stranded RNAs arranged in a closed loop without protein shell and that replicate in host plants where they may or may not be pathogenic. Viroid RNA is not translated and replicates by rolling circle mechanism without coding any proteins. This is in contrast to plant viruses where translation of viral genetic information is crucial for virus replication. Viroid hosts include both herbaceous and woody species - agronomic as well as ornamental. More than 30 species of viroids have been detected in many higher plants since they were discovered in 1971 by Diener. There are still considerable difficulties faced by growers in the control of viroid-caused diseases of economically important crops (Diener, 2007).

No information about the interaction of subviral pathogen, plant and elevated ozone concentration is available. Therefore, this study was aimed to find out if the presence of viroid infection can cause any differences in the phenotypic plant response to the short-term treatment with elevated ozone concentration under controlled environmental conditions using a model pathosystem formed from the model plant breed tomato (Lycopersicon esculentum Mill.) cv. 'Micro-Tom' and potato spindle tuber viroid (PSTVd). Tomato (Lycopersicon esculentum Mill.) cv. 'Micro-Tom' is widely accepted as a model plant breed in genetic and physiological studies (Matsukura et al., 2008). This model breed is known to be a suitable host in the studies of interaction of plant and the most common bacterial, fungal and viral pathogens (Takahashi et al., 2005; Sturbois et al., 2012). Here we tested the ability of tomato cv. 'Micro-Tom' to be exploited as a model host in the studies on viroid, host and ozone interaction. The advantage of this plant breed was susceptibility to potato spindle tuber viroid, short vegetation period, small size of the plants and good growth under controlled environmental conditions using relatively small amount of soil. The disadvantages we faced were low sensitivity of 'Micro-Tom' to the shortterm ozone treatment in the young age, absence of clear viroid-induced phenotypic symptoms, and slow viroid bioamplification under the optimal growth conditions.

\section{Material and methods}

Plant growth and inoculation. Tomato cv. 'Micro-Tom' plants were grown in the autoclaved commercially available substrate for tomato cultivation with $10 \%$ of perlite added in 2012 . Fertilizers N (100$\left.400 \mathrm{mg} \mathrm{l}^{-1}\right)$, P (50-200 $\left.\mathrm{mg} \mathrm{l}^{-1}\right)$, and $\mathrm{K}(100-500 \mathrm{mg}$ $\mathrm{1}^{-1}$ ) had been already added to the substrate, $\mathrm{pH}$ was 5-7. No additional fertilization was applied during the experiments. Plants were kept in the growth chamber with a photoperiod of $12 \mathrm{~h}$ at $20-25^{\circ} \mathrm{C}$ and watered with tap water 3-4 times per week. Two seeds per pot of $8 \times$ $8 \times 12 \mathrm{~cm}$ (for chronic and extreme treatment) and $6 \times$ $6 \times 8 \mathrm{~cm}$ (for acute treatment) were sown and only one seedling was left after germination. Mechanical viroid inoculation was carried out in 2-3 weeks after sowing when the second pair of true leaves appeared and was up to $5 \mathrm{~cm}$ long. Two leaves per plant were dusted with carborundum and rubbed after adding $20 \mu \mathrm{l}$ of tomato sap extract. Infected plant sap was taken from tomato cv. 'Micro-Tom' used for viroid bioamplification 70 days post inoculation (dpi). Plants were kept avoiding leaf contact between inoculated and uninoculated individuals.

Viroid detection. Systemic spread of viroid infection in inoculated plants was detected by two-step reverse transcription and polymerase chain reaction (RT-PCR) technique. Plant total ribonucleic acid (RNA) extraction was made from $0.1 \mathrm{~g}$ tissue taken from the top leaves of the plant. Samples for RNA extraction were taken 50-70 dpi. Plant total RNA was extracted using silica-based RNA extraction method (Menzel et al., 2002). Reverse transcription (RT) step to produce complementary deoxyribonucleic acid (cDNA) from template RNA was done as follows: a mixture of plant total RNA, reverse primer $(20 \mathrm{pmol})$ and nuclease free water (Thermo Fisher Scientific, Lithuania) was heated at $70^{\circ} \mathrm{C}$ for $10 \mathrm{~min}$ and chilled on ice. Then a mixture of $5 \times$ reaction buffer, $10 \mathrm{mM}$ mix of nucleotides (dNTP), 20 U ribonuclease inhibitor and $200 \mathrm{U}$ of Premium Revert AidTm Reverse Transcriptase (Thermo Fisher Scientific) was added and RT step was continued at $50^{\circ} \mathrm{C}$ for $60 \mathrm{~min}$. After the RT step, PCR reactions were set up containing $2 \mu \mathrm{L}$ of cDNA, antisense and sense primer (each of $20 \mathrm{pmol}), \mathrm{MgCl}_{2}(0.7 \mathrm{mM}), \mathrm{dNTP} \operatorname{mix}(0.2 \mathrm{mM}), 10 \times$ PCR reaction buffer and $1 \mathrm{U}$ of Hot start Taq polymerase ("Thermo Fisher Scientific"). Amplification (PCR) step was done as follows: 35 cycles of $30 \mathrm{sec}$ at $94^{\circ} \mathrm{C}$, $30 \mathrm{sec}$ at $60^{\circ} \mathrm{C}, 30 \mathrm{sec}$ at $72^{\circ} \mathrm{C}$ were followed by cDNA denaturation for $3 \mathrm{~min}$ at $94^{\circ} \mathrm{C}$ and finished with a final extension for $5 \mathrm{~min}$ at $72^{\circ} \mathrm{C}$. Primers by Weidemann and Buchta (1998) were used for whole length PSTVd amplification. As negative control, reactions containing no template RNA and RNA extracted from healthy plants were used in RT-PCR reactions. To test quality of RTPCR with the infected samples whether the reactions were not inhibited by remains of silica, polysaccharides, etc., a series of RT-PCR reactions with the samples from the same plants was performed with universal plant 5S rRNA specific primers (Kolchinsky et al., 1991). Products of RT-PCR reactions were analyzed on $5 \%$ polyacrylamide gel after staining with ethidium bromide.

Ozone treatment. Chronic treatment was applied by exposing plants to $80 \mathrm{ppb}$ ozone concentration for 8 hours during the light period. In this experiment 15 viroid-uninoculated and 15 inoculated plants were ozoneexposed on day 7 post inoculation while 10 inoculated plants and 10 uninoculated plants were kept in ambient ozone concentration under the same environmental conditions. Acute treatment was applied by exposing plants to $400 \mathrm{ppb}$ ozone concentration for 6 hours during the light period. In this experiment 20 uninoculated and 20 inoculated plants were ozone-exposed on day 7 post inoculation while 20 inoculated plants and 20 uninoculated plants were kept in the ambient ozone concentration under the same environmental conditions. 
Extreme treatment was applied by exposing plants to $300 \mathrm{ppb}$ ozone concentration for 13 hours $(6,4$ and $3 \mathrm{~h}$, respectively on the first, second and third day) during the light period. In this experiment 5 uninoculated and 5 inoculated plants were submitted to ozone treatment 60 days post inoculation while 5 inoculated plants and 5 uninoculated plants were kept in the ambient ozone concentration under the same environmental conditions. Ozone fumigation was carried out in the closed top chamber under conditions that were very close to the ones in the growth chamber. Control plants were kept in the separate chamber at ambient ozone concentration during the time of ozone fumigation. Ozone concentration was measured continuously with the UV absorption ozone analyzer O341M (Environnement S. A., France) by averaging data of 1 minute. Limits of the measurements with the ozone analyzer were $0-1000 \mathrm{ppb}$ and sensitivity $-1 \mathrm{ppb}$. Ozone in the chamber was generated by ozone generator OZX-B300T (Enaly Ozone Ltd., Canada).

Statistical analysis. Height of viroid inoculated and uninoculated plants was measured at the end of the growth period. The mean, variance and t-test were calculated using Excel software of Microsoft Office 2003. The significance of the difference between means within each treatment was examined applying Student's $t$-test considering unequal variance of two-samples and twotailed distribution.

\section{Results and discussion}

Spread of the viroid infection in plants. No significant differences in phenotypes between viroid inoculated and uninoculated plants of tomato $\mathrm{cv}$. 'Micro-Tom' under the optimal growth conditions had been observed. Systemic spread of viroid infection and bioamplification of viroid RNA in the tomato cv. 'MicroTom' grown in the temperature of $20-25^{\circ} \mathrm{C}$ was very slow. The presence of viroid infection by RT-PCR was hardly detectable on $21 \mathrm{dpi}$. Better results were obtained using RNA extracted on day $30 \mathrm{dpi}$. However, the viroid titers obtained were highly variable among the plants, in contrast to the titers of plant ribosomal RNA used as an internal control (Pic. 1). Variation in viroid titers could be caused by different viroid concentration in the inoculum.

Effect of chronic ozone treatment. Only slight yellowing of the plant top leaves was observed in the plants exposed to $80 \mathrm{ppb}$ of ozone for 8 hours. There were no significant differences observed in plant response to this ozone treatment in the phenotypic appearance as well as in plant growth (Table 1). These results indicated that naturally occurring single short-term peaks of elevated ozone concentration would have no any significant impact on viroid and host interaction at least in the model pathosystem exploited for this study.

Effect of acute ozone treatment. Typically ozone-caused necrotic spots appear on leaves of ozonesensitive plants shortly after the exposure under acute ozone treatment (Sanderman, 1996; Krupa et al., 2001). In our experiment, acute ozone treatment carried out on 2-3 week old plants, never caused the appearance of necrotic spots on the treated leaves. However, the differences in leaf colour between viroid-infected and uninfected plants started to show two weeks after ozone exposure. Initially, an outbreak of red colour appeared on

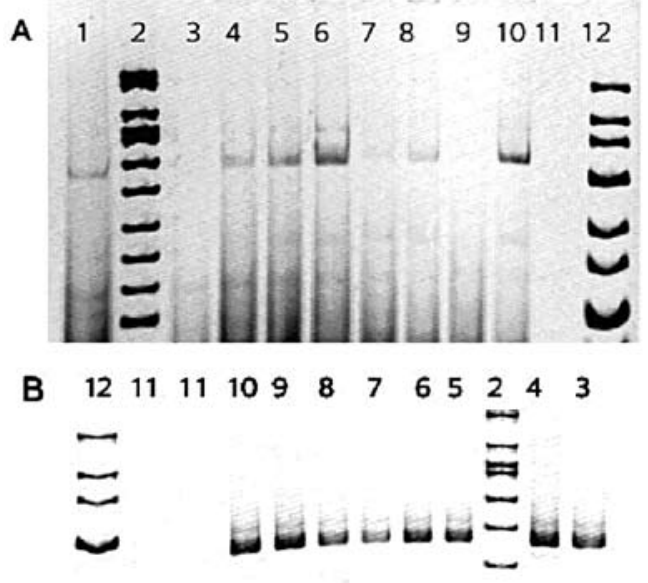

Notes. A - whole length of potato spindle tuber viroid (PSTVd) amplicons obtained using PSTVd-specific primers; $\mathrm{B}$ - amplicons obtained using primers for internal ribonucleic acid (RNA) control. Lane 1 - positive PSTVd control, lane 2 - deoxyribonucleic acid (DNA) marker pUC mix 8 (Thermo Fisher Scientific, SM0301), lane 12 - low range DNA marker (Thermo Fisher Scientific, SM0383), lanes 3 and 9 - samples from uninoculated plants (negative controls), lanes 4-8 and 10 - PSTVd-infected plants, lane 11a and $11 \mathrm{~b}$ - water negative controls of PCR and RT with PCR reactions, respectively.

Picture 1. Amplicons obtained after reverse transcription (RT) and polymerase chain reaction (PRC) using samples picked up from the plants 30 days post inoculation (dpi)

Table 1. Effect of ozone treatment on the height of the viroid inoculated and uninoculated plants at the end of growth season

\begin{tabular}{|c|c|c|c|}
\hline \multirow{2}{*}{$\begin{array}{l}\text { Ozone } \\
\text { treatment }\end{array}$} & \multicolumn{2}{|c|}{ Average height $(\mathrm{cm})$ of } & \multirow{2}{*}{$\begin{array}{c}\text { Significance } \\
\text { level }\end{array}$} \\
\hline & $\begin{array}{l}\text { viroid-infected } \\
\text { plants }\end{array}$ & $\begin{array}{l}\text { viroid-uninfected } \\
\text { plants }\end{array}$ & \\
\hline Chronic & 16.9 & 17.3 & n.s. \\
\hline Acute & 9.1 & 12.9 & $* * *$ \\
\hline Extreme & 12.7 & 16.8 & $*$ \\
\hline
\end{tabular}

Notes. Differences between viroid-inoculated and uninoculated plants revealed by Student's $t$-test are: n.s. - non significant, * - significant at $p<0.05$ level and $* * *$ - significant at $p<0.001$ level. Chronic, acute and extreme ozone treatments were fulfilled by keeping plants in the chamber with ozone concentration 80 , 400 and 300 ppb for 8,6 and 13 hours, respectively.

the leaves of viroid-infected plants. At the end of growth season, ozone-exposed viroid-uninoculated plants had a higher degree of defoliation than viroid-inoculated ozone-exposed or uninoculated ozone-untreated plants (Pic. 2).

It was observed a long time ago that presence of virus infection can reduce air pollution-caused injury in commercially-grown plants that are sensitive to ozone (Davis, Smith, 1974; Bisessar, Temple, 1977). However, only several plant species sensitive to ozone and susceptible to certain virus species were used as experimental hosts in the studies of ozone stress effect on virus-infected plants. Tobacco (Nicotiana tobacum L.), woodland tobacco (Nicotiana sylvestris Speg. and S. Comes), soybean 


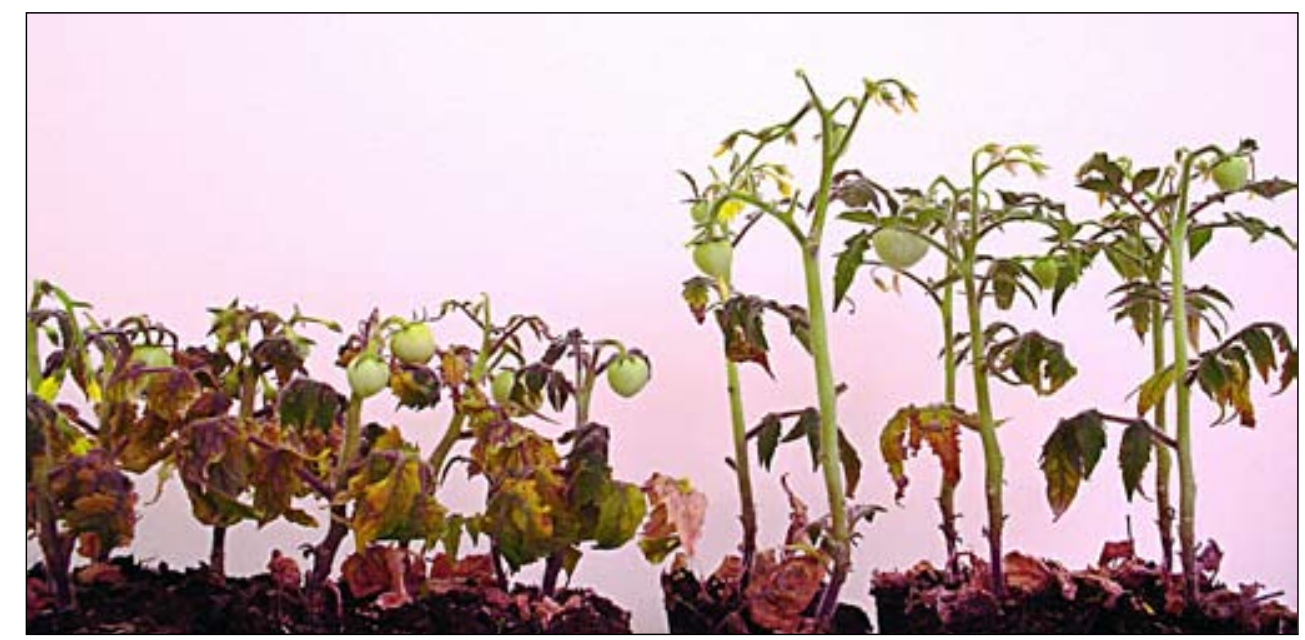

Picture 2. Differences in the plant height and the degree of defoliation observed between viroid-infected (on the left) and uninfected (on the right) tomatoes (Lycopersicon esculentum Mill.) cv. 'Micro-Tom' in six weeks after acute ozone treatment $(400 \mathrm{ppb} \times 6 \mathrm{~h})$ carried on young plants

(Glycine max L.), white clover (Trifolium repens L.), pinto bean (Phaseolus vulgaris L.), wild oats (Avena fatua L.) and tomato (Lycopersicon esculentum Mill.) were among them. Tomato is an economically important crop. It is sensitive to ozone and many pathogens but sensitivity to ozone and viral infection was found to differ remarkably among the cultivars (Ormrod, Kemp 1979; Arie et al., 2007; Calvo et al., 2007). No study on the response of tomato cv. 'Micro-Tom' to ozone treatment was found to be done; however, the effect of oxidative stress and activity of antioxidant enzymes were examined by several authors (Li et al., 2004; Gratao et al., 2008). The results of our experiment revealed no visible injury caused by ozone treatment on young tomato cv. 'MicroTom' plants. However, statistically significant (at 99.9\% level) differences in plant height were found at the end of growth period after exposure of plants to the acute ozone treatment (Table 1) which well corresponds to the other reports that ozone could inhibit growth and development of plants.

Extreme ozone treatment. Extreme ozone treatment was carried out three days in a row exposing mature plants to $300 \mathrm{ppb}$ ozone concentration during light period for 6 hours on day 1, for 4 hours on day 2 and for 3 hours on day 3. Rapid appearance of necrotic spots on plant leaves was observed within the hours after treatment on day 3. All leaves that had been exposed to ozone were dropped in few days. One infected plant died after this treatment while the others survived and regenerated new shoots, leaves, flowers and fruits. Clear differences between viroid-inoculated and uninoculated plants were noticed in regeneration capacity. Uninoculated plants fully recovered after the stress: they produced new shoots, leaves, flowers, fruits and seeds. Necrotic spots were visible even on the newly emerged leaves of viroid infected plants. Most interestingly, the regenerated shoots of ozone-treated viroid-infected plants were much shorter had smaller flowers, fruits and produced no seeds as compared to the old ozone-exposed shoots of the same plants (Pic. 3). However, viroid infection in regenerated leaves of the exposed plants was still present only in very low titers and was hardly detectable by RT-PCR.

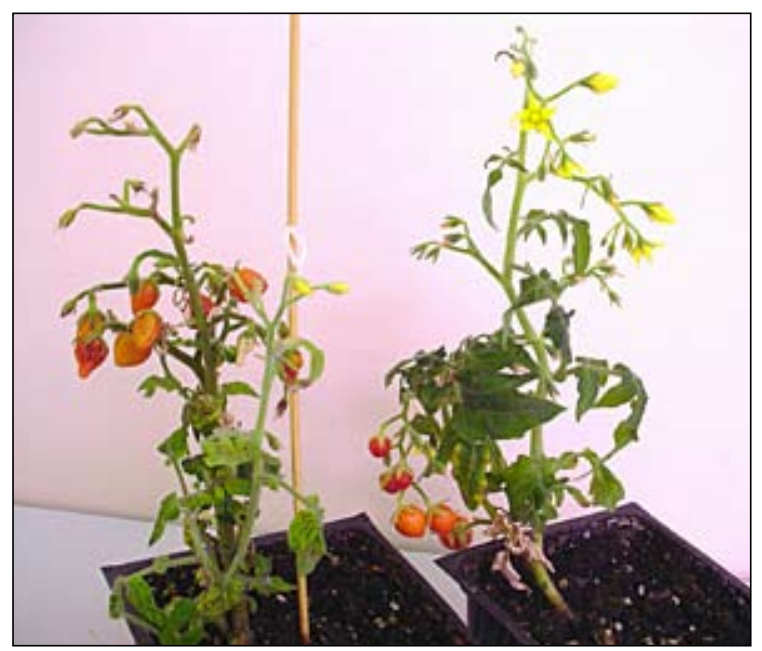

Picture 3. Regeneration of tomato (Lycopersicon esculentum Mill.) cv. 'Micro-Tom' plants exposed to extreme ozone treatment $(400 \mathrm{ppb} \times 13 \mathrm{~h})$ : potato spindle tuber viroid-infected plant (on the left) and uninfected plant (on the right)

Tomato cv. 'Micro-Tom' harbours some mutated genes yielding the size reduction and dwarf appearance (Marti et al., 2006). The latest research on viroids revealed that the marked upregulation of genes involved in the response to viroid infection of the dwarf cv. 'MicroTom' was noticed only when exogenous brassinosteroid was applied to infected plants, thereby providing the first evidence for the involvement of brassinosteroidmediated signalling in viroid disease induction (Owens et al., 2012). This is why different response in host and pathogen interaction might be observed in the case of different experimental pathosystem. Our results in Table 2 show that appearance of phenotypic alterations caused by the presence of viroid infection in plants was highly dependent on the dose of ozone received by plants during the short-term ozone treatment.

A huge number of soybean transcripts showing significant changes in general expression as a response to combined effect of elevated ozone and soybean mosaic virus infection is known (Bilgin et al., 2008). This combination caused statistically significant changes 
in differential expression to virus and ozone of 369 and 231 of soybean transcripts respectively at 8 and 72 hours post infection. Viroid is an obligate parasite of the host transcriptional machinery. Changes in the transcription level of the big amount of host genes could be the reason why changes occurring in viroid pathogenicity included different phenotypic traits depending on the level of stress caused by oxidative stress.

Table 2. Changes in phenotypic appearance of tomato cv. 'Micro-Tom' caused by potato spindle tuber viroid (PSTVd) infection depending on the dose of ozone received by plants during the short-term ozone treatment under controlled environment

\begin{tabular}{cccc}
\hline \multirow{3}{*}{$\begin{array}{c}\text { Concentration } \\
\text { Ozone }\end{array} \begin{array}{c}\text { exposure } \\
\text { treatment }\end{array}$} & $\begin{array}{c}\text { Phenotypic effect on submitted plants } \\
\text { hours }\end{array}$ & viroid-inoculated & viroid-uninoculated \\
\cline { 3 - 4 } Chronic & $80 \times 8$ & $\begin{array}{c}\text { non-significant } \\
\text { effect }\end{array}$ & $\begin{array}{c}\text { non-significant } \\
\text { effect }\end{array}$ \\
\hline Acute & $400 \times 6$ & $\begin{array}{c}\text { discolouration, } \\
\text { growth reduction, }\end{array}$ & leaf defoliation \\
\hline Extreme & $300 \times 13$ & $\begin{array}{c}\text { poor regeneration, } \\
\text { visual injury on } \\
\text { new leaves, no } \\
\text { seed production }\end{array}$ & $\begin{array}{c}\text { full recovery, } \\
\text { regeneration of } \\
\text { healthy leaves }\end{array}$ \\
\hline
\end{tabular}

The results of our study indicated that the experimental pathosystem of tomato cv. 'Micro-Tom' and potato spindle tuber viroid could be useful in the studies of pollution pathology and could provide new evidence on changes in viroid pathogenicity under the very high environmental pressure of elevated ozone concentration.

\section{Conclusions}

1. The results of our investigation indicated that the experimental pathosystem of tomato (Lycopersicon esculentum Mill.) cv. 'Micro-Tom' and potato spindle tuber viroid (PSTVd) could be useful in the studies of pollution pathology and could provide new evidence on the presence of interaction among sub-viral pathogen, plant and elevated ozone concentration considering the phenotypic response during the whole growth period.

2. There were no significant differences observed in the degree of visible ozone injury between viroid-inoculated and uninoculated plants shortly after the short-term chronic $(80 \mathrm{ppb} \times 8 \mathrm{~h})$, acute $(400 \mathrm{ppb} \times$ $6 \mathrm{~h})$ or extreme $(300 \mathrm{ppb} \times 13 \mathrm{~h})$ ozone exposure.

3. Significant differences in plant growth, degree of defoliation and regeneration capacity were found between viroid-inoculated and uninoculated plants after acute and extreme ozone treatments had been applied, indicating that pathogenicity of PSTVd could be altered under very high environmental pressure caused by elevated ozone concentration.

\section{Acknowledgments}

We greatly acknowledge financial support from the Research Council of Lithuania, grant No. MIP$119 / 2011$.

Received 28122012

Accepted 09042013

\section{References}

Arie T., Takahashi H., Kodama M., Teraoka T. 2007. Tomato as a model plant for plant-pathogen interactions. Plant Biotechnology. 24: 135-147 http://dx.doi.org/10.5511/plantbiotechnology.24.135

Bilgin D. D., Aldea M., O'Neill B. F., Benitez M., Li M., Clough S. J., DeLucia E. H. 2008. Elevated ozone alters soybeanvirus interaction. Molecular Plant-Microbe Interactions, 21 (10): 1297-130 http://dx.doi.org/10.1094/MPMI-21-10-1297

Bisessar S., Temple P. J. 1977. Reduced ozone injury on virusinfected tobacco in the field. Plant Disease Reporter, 61: 961-963

Booker F. L., McGrath R. M. M., Burkey K. O., Decoteau D., Fiscus E. L., Manning W., Krupa S., Chappelka A., GrantzD. A. 2009. The ozone component of global change: Potential effects on agricultural and horticultural plant yield, product quality and interactions with invasive species. Journal of Integrative Plant Biology, 51: 337-351 http://dx.doi.org/10.1111/j.1744-7909.2008.00805.x

Brennan E., Leone I. A. 1969. Suppression of ozone toxicity symptoms in virus-infected tobacco. Phytopathology, 59: 263-264

Calvo E., Martin C., Sanz M. J. 2007. Ozone sensitivity differences in five tomato cultivars: visible injury and effects on biomass and fruits. Water. Air and Soil Pollution, 186: 167-181 http://dx.doi.org/10.1007/s11270-007-9475-0

Davis D. D., Smith S. H. 1974. Reduction of ozone-sensitivity of pinto bean by bean common mosaic virus. Phytopathology, 64: 383-385 http://dx.doi.org/10.1094/Phyto-64-383

Diener T. O. 2007. Inducted in 2007 for his pioneering work in plant pathology has enabled the control of viroid diseases of many crops. <http://chembio-newsarchive.umd.edu/about/ circleofdiscovery/theodorodiener $>$ [accessed 1707 2013]

Gratao P. L., Monteiro C. C., Antunes A. M., Peres L. E. P., Azevedo R. A. 2008. Acquired tolerance of tomato (Lycopersicon esculentum cv. Micro-Tom) plants to cadmium-induced stress. Annals Applied Biology, 153: $321-333$ http://dx.doi.org/10.1111/j.1744-7348.2008.00299.x

Hayes F., Jones M. L. M., Mills G., Ashmore M. 2007. Metaanalysis of the relative sensitivity of semi-natural vegetation species to ozone. Environmental Pollution. 146: 754-762 http://dx.doi.org/10.1016/j.envpol.2006.06.011

Heagle A. S., McLaughlin M. R., Miller J. E., Joyner R. I. 1992. Response of two white clover clones to peanut stunt virus and ozone. Phytopathology, 82: 254-258 http://dx.doi.org/10.1094/Phyto-82-254

Kolchinsky A., Kolesnikova M., Ananiev E. 1991. Portraying of plant genomes using polymerase chain reaction amplification of ribosomal 5S genes. Genome, 34: 1028$1031 \mathrm{http} / / / \mathrm{dx}$. doi.org/10.1139/g91-158

Krupa S., McGrath M.T.,Andersen C., BookerF.L., Burkey K. O., Chappelka A., Chevone B., Pell E., Zilinskas B. 2001. Ambient ozone and plant health. Plant Disease, 85: 4-17 http://dx.doi.org/10.1094/PDIS.2001.85.1.4

Li L., Zhao Y., McCaig B. C., Wingerd B. A., Wang J., Whalon M. E., Pichersky E., Howe G. A. 2004. The tomato homolog of CORONATINE-INSENSITIVE1 is required for the maternal control of seed maturation, jasmonate-signalled defence responses, and glandular trichome development. The Plant Cell, 16 (1): 126-143 http://dx.doi.org/10.1105/tpc.017954

Marti E., Gisbert C., Bishop G. J., Dixon S. M., Garcia-Martinez J. L. 2006. Genetic and physiological characterization of tomato cv. Micro-Tom. Journal of Experimental Botany, 57 (9): 2037-2047 http://dx.doi.org/10.1093/jxb/erj154

Matsukura C., Aoki K., Fukuda N., Mizoguchi T., Asamizu E., Saito T., Shibata D., Ezura H. 2008. Comprehensive resources for tomato functional genomics based on the miniature model tomato Micro-Tom. Current Genomics. 9: 436-443 http://dx.doi.org/10.2174/138920208786241225 
Menzel W., Jelkmann W., Maiss E. 2002. Detection of four apple viruses by multiplex RT-PCR assays with coamplification of plant mRNA as internal control. Journal of Virological Methods. 99: 81-92 http://dx.doi.org/10.1016/S0166-0934(01)00381-0

Morgan P. B., Ainworths E. A., Long S. P. 2003. How does elevated ozone impact soybean? A metaanalysis of photosynthesis, growth and yield. Plant, Cell and Environment. 26 (8): 1317-1328 http://dx.doi.org/10.1046/j.0016-8025.2003.01056.x

Ormrod D. P., Kemp W. G. 1979. Ozone response of tomato plants infected with cucumber mosaic virus and/or tobacco mosaic virus. Canadian Journal of Plant Science, 59: 1077-1083 http://dx.doi.org/10.4141/cjps79-167

Overmyer K., Brosche M., Pellinen R., Kuittinen T., Tuominen H., Ahlfors R., Keinanen M., Saarma M., Scheel D., Kangasjarvi J. 2005. Ozone-induced programmed cell death in the Arabidopsis radical-induced cell death1 mutant. Plant Phvsiologv. 137: 1092-1104 http://dx.doi.org/10.1104/pp.104.055681

Owens R. A., Tech K. B., Shao J. Y., Sano T., Baker C. J. 2012. Global analysis of tomato gene expression during potato spindle tuber viroid infection reveals a complex array of changes affecting hormone signalling. Molecular Plant Microbe Interaction. 25 (4): 582-598 http://dx.doi.org/10.1094/MPMI-09-11-0258

Pollina E. C., Power A. G., Sparks J. P. 2008. Effects of elevated ozone on transmission and symptom severity of a generalist plant virus. $<$ http://eco.confex.com/eco/2008/ techprogram/P10910.HTM $>$ [accessed 1712 2012]

Rao M. V., Davis K. R. 2001. The physiology of ozone induced cell death. Planta. 213: 682-690 http://dx.doi.org/10.1007/s004250100618
Reinert R. A., Gooding G. V. Jr. 1978. Effect of ozone and tobacco streak virus alone and in combination on Nicotiana tahacum. Phytonathologv. 68: 15-17 http://dx.doi.org/10.1094/Phyto-68-15

Sandermann H. Jr. 1996. Ozone and plant health. The Annual Review of Phytonathology. 34: 347-366 http://dx.doi. org/10.1146/annurev.phyto.34.1.347

Sturbois B., Dubrana-Ourabah M. P., Gombert J., Lasseur B., Macquet A., Faure C., Bendahmane A., Baurès I., Candresse T. 2012. Identification and characterization of tomato mutants affected in the $\mathrm{Rx}$-mediated resistance to PVX isolates. Molecular Plant Microbe Interaction, 25 (3): 341-354 http://dx.doi.org/10.1094/MPMI-07-11-0181

Takahashi H., Shimizu A., Arie T., Rosmalawati S., Fukushima S., Kikuchi M., Hikichi Y., Kanda A., Takahashi A., Kiba A., Ohnishi K., Ichinose Y., Taguchi F., Yasuda C., Kodama M., Egusa M., Matsuta C., Sawada H., Shibata D., Hori K., Watanabe Y. 2005. Catalogue of Micro-Tom tomato responses to common fungal, bacterial, and viral nathogens. Journal of General Plant Pathology, 71: 8-22 http://dx.doi.org/10.1007/s10327-004-0168-x

Vargo R. H., Pell E. J., Smith S. H. 1978. Induced resistance to ozone injury of soybean by tobacco ringspot virus. Phytonathologv, 68: 715-719 http://dx.doi.org/10.1094/Phyto-68-715

Weidemann H. L., Buchta U. 1998. A simple and rapid method for the detection of potato spindle tuber viroid (PSTVd) by RT-PCR. Potato Research. 41 (1): 1-8 http://dx.doi.org/10.1007/BF02360256

ISSN 1392-3196 / e-ISSN 2335-8947

Zemdirbyste-Agriculture, vol. 100, No. 3 (2013), p. 277-282

DOI $10.13080 /$ z-a.2013.100.035

\title{
Skirtingų ozono doziụ poveikis bulvių verpstiškumo viroidu užkrèstiems valgomojo pomidoro (Lycopersicon esculentum Mill.) augalams
}

\author{
A. Abraitienè $\dot{ }^{1}, R$. Girgždiene் $\dot{e}^{1,2}$ \\ ${ }^{1}$ Vilniaus universiteto Biotechnologijos institutas \\ ${ }^{2}$ Fizinių ir technologijos mokslų centro Fizikos institutas
}

\section{Santrauka}

Tyrimo metu siekta išsiaiškinti, ar užkrètimas viroidu gali pakeisti augalo fenotipinị atsaką ị trumpalaikị poveiki didelès koncentracijos ozonu. Siekiant nustatyti, ar didelè ozono koncentracija gali turèti esminès įtakos šio ligu sukèlëjo patogeniškumui ir plitimui, buvo atlikti trys viroidu užkrėstų augalų trumpalaikio poveikio skirtingomis ozono koncentracijomis $(80 \mathrm{ppb} \times 8$ val., $400 \mathrm{ppb} \times 6$ val. ir $300 \mathrm{ppb} \times 13$ val. $)$ eksperimentai. Tam buvo pritaikyta modelinè patosistema, kurioje veislès 'Micro-Tom' pomidorai buvo panaudoti kaip subvirusinio patogeno, bulvių gumbų verpstiškumo viroido, šeimininkas.

Tyrimų rezultatai parodè, kad viroidu užkrèstų augalų fenotipiniai pokyčiai buvo labai priklausomi nuo ozono dozès, kuria buvo paveikti augalai. Užkrèstus augalus 8 valandas paveikus 80 ppb ozono koncentracija, buvo pastebètas tik nežymus viršūnès pageltimas. Nei esminių augalų fenotipo, nei augimo pokyčių, nulemtų tokio ozono poveikio nebuvo nustatyta. Tai rodo, jog trumpalaikiai gamtoje aptinkami ozono koncentracijos pakilimai neturi didesnès itakos augalo šeimininko ir viroido sąveikai. Trumpalaikis augalu poveikis didelèmis koncentracijomis $(400 \mathrm{ppb} \times 6$ val. ir $300 \mathrm{ppb} \times 13$ val.) ozono tuojau pat po poveikio nesukèle esminių skirtumų tarp viroidu užkrèstų ir neužkrėstų augalų matomų pažeidimų. Tačiau augimo laikotarpio pabaigoje tarp augalų, kuriems buvo taikytas toks poveikis, išryškèjo žymūs augimo, defoliacijos ir atžèlimo skirtumai, rodantys, jog stiprus ozono streso poveikis gali turèti didelès įtakos bulvių verpstiškumo viroido patogeniškumui.

Reikšminiai žodžiai: bulvių gumbų verpstiškumo viroidas, patogeniškumas, trumpalaikis ozono poveikis. 